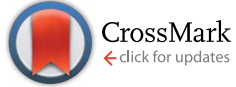

Cite this: J. Mater. Chem. A, 2015, 3 , 9194 Accepted 8th December 2014

DOI: $10.1039 / c 4 t a 06198 \mathrm{e}$

www.rsc.org/MaterialsA
Received 15th November 2014

\section{Effect of different lead precursors on perovskite solar cell performance and stability $\dagger$}

\author{
Fadi Kamal Aldibaja, Laura Badia, Elena Mas-Marzá, ${ }^{*}$ Rafael S. Sánchez, Eva M. Barea \\ and Ivan Mora-Sero*
}

We present the use of halide $\left(\mathrm{PbCl}_{2}\right)$ and non-halide lead precursors $\left(\mathrm{Pb}(\mathrm{OAc})_{2}\left(\mathrm{OAc}=\mathrm{CH}_{3} \mathrm{CH}_{2} \mathrm{COO}^{-}\right)\right.$, $\mathrm{Pb}\left(\mathrm{NO}_{3}\right)_{2}, \mathrm{~Pb}(\mathrm{acac})_{2}\left(\mathrm{acac}=\left(\mathrm{CH}_{3} \mathrm{COCHCOCH}_{3}\right)^{-}\right)$and $\left.\mathrm{PbCO}_{3}\right)$ for the preparation of perovskite solar cells. We have confirmed by $\mathrm{X}$-ray diffraction the growth of $\mathrm{CH}_{3} \mathrm{NH}_{3} \mathrm{Pbl}_{3}$ in all the analyzed cases, except for $\mathrm{PbCO}_{3}$, independently of the lead precursor used for the synthesis of the perovskite. In addition, different cell configurations, thin films and mesoporous scaffolds, $\mathrm{TiO}_{2}$ or $\mathrm{Al}_{2} \mathrm{O}_{3}$, have also been prepared. We have observed that the lead precursor has a strong influence on the structural properties of perovskite (grain size), as well as on the solar cell performance. Photovoltaic conversion efficiencies comparable to those achieved when using the commonly employed $\mathrm{PbCl}_{2}$ have been obtained with $\mathrm{Pb}(\mathrm{OAc})_{2}$ as a lead source. Stability studies of the perovskite films and devices have also been carried out, which demonstrate that the lead precursor also plays a role. The stability is not only strongly affected by atmosphere and illumination conditions, but also by the lead precursor employed for the perovskite synthesis. These results highlight that other lead sources, different to the commonly used $\mathrm{PbCl}_{2}$ and $\mathrm{Pbl}_{2}$, are also suitable for the development of PSCs, opening a new way for device performance optimization.

\section{Introduction}

Nowadays, hybrid halide perovskites with the general formula $\mathrm{ABX}_{3}$, where $\mathrm{X}=\mathrm{Cl}, \mathrm{Br}$ or $\mathrm{I}$, can be considered, without any doubts, as ideal candidates for the preparation of photovoltaic devices. The most successful and commonly used hybrid halide perovskite for photovoltaic applications has been $\mathrm{CH}_{3} \mathrm{NH}_{3} \mathrm{PbI}_{3}$ and its analogue prepared from lead chloride, commonly denoted as $\mathrm{CH}_{3} \mathrm{NH}_{3} \mathrm{PbI}_{3-x} \mathrm{Cl}_{x}{ }^{1-3}$ The first example of the use of hybrid halide perovskites in solar cells was reported by Miyasaka in $2009,{ }^{4}$ and from that moment the field of Perovskite Solar Cells (PSCs) has experienced the best ever efficiency enhancement within an outstandingly short period of time. ${ }^{5}$ In 2012, the use of perovskite for photovoltaic devices took a step forward with the preparation of all-solid devices with spiroOMeTAD, as a selective contact and Hole Transporting Material (HTM), producing $10-11 \%$ efficiency. ${ }^{6,7}$ Since then, numerous research groups have focused their efforts on the development of different approaches to optimize this field, mainly based on the use of different cell configurations $\left(\mathrm{TiO}_{2}\right.$ or $\mathrm{Al}_{2} \mathrm{O}_{3}$ scaffolds or planar configurations with no scaffold), use of mixed halide (Br-I) derivatives of $\mathrm{CH}_{3} \mathrm{NH}_{3} \mathrm{PbI}_{3},{ }^{8-10}$ exchange of the organic

Photovoltaics and Optoelectronic Devices Group, Departament de Física, Universitat Jaume I, 12071 Castelló, Spain.E-mail: emas@uji.es; sero@uji.es

$\dagger$ Electronic supplementary information (ESI) available. See DOI: 10.1039/c4ta06198e cation $\mathrm{CH}_{3} \mathrm{NH}_{3}{ }^{+11-14}$ use of additives in the $\mathrm{HTM}^{15,16}$ or use of different selective contacts. ${ }^{17-20}$ In addition, high efficiency samples have been obtained from a broad variety of deposition techniques, including spin-coating ${ }^{6,7}$ two step procedures involving dip-coating ${ }^{21}$ or drop casting methods ${ }^{22}$ and solvent engineering strategies. ${ }^{1}$ Besides, evaporation procedures have also been demonstrated to be excellent processes for the preparation of perovskite films. ${ }^{23}$

Although perovskites $\mathrm{CH}_{3} \mathrm{NH}_{3} \mathrm{PbI}_{3}$ and $\mathrm{CH}_{3} \mathrm{NH}_{3} \mathrm{PbI}_{3-x} \mathrm{Cl}_{x}$ are normally prepared by the reaction in a solution of $\mathrm{CH}_{3} \mathrm{NH}_{3} \mathrm{I}$ and $\mathrm{PbI}_{2}$ in a $1: 1$ ratio or $\mathrm{CH}_{3} \mathrm{NH}_{3} \mathrm{I}$ and $\mathrm{PbCl}_{2}$ in a $3: 1$ ratio, other non-halide lead precursors such as lead acetate, $\mathrm{Pb}(\mathrm{OAc})_{2}$ or lead nitrate, $\mathrm{Pb}\left(\mathrm{NO}_{3}\right)_{2}$, are also known to be appropriate candidates for the synthesis of these materials. ${ }^{\mathbf{2 4 - 2 6}}$ However, most of these perovskites, synthesized from nonhalide precursors, have not been analyzed in complete photovoltaic devices yet. Therefore, in this article we study the performance and stability of PSCs prepared from non-halide lead precursors. These cells were prepared in mesoporous heterojunction configuration glass/FTO/compact $\mathrm{TiO}_{2} /$ mesoporous scaffold/ $\mathrm{CH}_{3} \mathrm{NH}_{3} \mathrm{PbI}_{3} /$ spiro-OMeTAD/Au, with the $\mathrm{TiO}_{2}$ or $\mathrm{Al}_{2} \mathrm{O}_{3}$ scaffold, and planar configuration glass/FTO/compact $\mathrm{TiO}_{2} /$ $\mathrm{CH}_{3} \mathrm{NH}_{3} \mathrm{PbI}_{3}$ /spiro-OMeTAD/Au. The performance and stability have been compared to those obtained with the solar cells prepared with the lead chloride precursor, $\mathrm{CH}_{3} \mathrm{NH}_{3} \mathrm{PbI}_{3-x} \mathrm{Cl}_{x}$, as reference. We have observed that the lead precursor employed affects dramatically the perovskite morphology and crystal size, 
even though the same experimental procedures were followed for the synthesis. Furthermore, preliminary studies of the stability of both perovskite films and PSCs have also been performed and compared with $\mathrm{CH}_{3} \mathrm{NH}_{3} \mathrm{PbI}_{3-x} \mathrm{Cl}_{x}$.

\section{Experimental section}

\section{Substrate preparation}

Fluorine doped tin oxide (FTO) coated glass substrates $(25 \times$ $25 \mathrm{~mm}$, Pilkington TEC15, $\sim 15 \Omega \mathrm{sq}^{-1}$ resistance) were etched with zinc powder and $\mathrm{HCl}(2 \mathrm{M})$ to obtain $0.224 \mathrm{~cm}^{2}$ of active electrode area. The substrates were cleaned with soap (Hellmanex) and rinsed with Milli-Q water and ethanol. Then, the sheets were sonicated for 15 minutes in a solution of acetone : isopropanol $(1: 1 \mathrm{v} / \mathrm{v})$, rinsed with ethanol and dried with compressed air. After that, a UV/ozone treatment was performed for 15 minutes. Then, a $\mathrm{TiO}_{2}$ blocking layer was deposited onto the substrates by spray pyrolysis at $450{ }^{\circ} \mathrm{C}$, using a titanium diisopropoxide bis(acetylacetonate) (75\% in isopropanol, Sigma-Aldrich) solution diluted in ethanol (1 : 39, $\mathrm{v} / \mathrm{v}$ ), with oxygen as the carrier gas. After the spraying process, the films were kept at $450{ }^{\circ} \mathrm{C}$ for 5 minutes.

\section{Mesoporous $\mathrm{TiO}_{2}$ layer}

When needed, a mesoporous $\mathrm{TiO}_{2}$ layer was deposited by spin coating at $4000 \mathrm{rpm}$ for $60 \mathrm{~s}$ using a $\mathrm{TiO}_{2}$ paste (Dyesol 18NRT, $20 \mathrm{~nm}$ average particle size) diluted in terpineol $(1: 3$, weight ratio). After drying at $80{ }^{\circ} \mathrm{C}$, the $\mathrm{TiO}_{2}$ layers were heated at $470{ }^{\circ} \mathrm{C}$ for $30 \mathrm{~min}$ and cooled to room temperature. The thickness determined by Scanning Electron Microscopy was $\sim 200 \mathrm{~nm}$.

\section{Mesoporous $\mathrm{Al}_{2} \mathrm{O}_{3}$ layer}

When needed, a mesoporous $\mathrm{Al}_{2} \mathrm{O}_{3}$ layer was deposited by spin coating at $2500 \mathrm{rpm}$ for $60 \mathrm{~s}$ using a colloidal dispersion of $<50 \mathrm{~nm} \mathrm{Al}{ }_{2} \mathrm{O}_{3}$ nanoparticles in isopropanol, followed by drying at $150{ }^{\circ} \mathrm{C}$ for 30 minutes. The thickness determined by scanning electron microscopy was $\sim 200 \mathrm{~nm}$.

\section{Perovskite deposition}

The perovskite precursor solution $(100 \mu \mathrm{l})$, prepared by reacting $2.64 \mathrm{mmol}$ of methylammonium iodide and $0.88 \mathrm{mmol}$ of the corresponding lead precursor at a $3: 1$ molar ratio in $1 \mathrm{~mL}$ of DMF, was spin-coated inside the glove box at 2000 r.p.m. for $60 \mathrm{~s}$. After the deposition, the substrate was kept at $100^{\circ} \mathrm{C}$ for $10 \mathrm{~min}$. Next, the substrates were heated at $100{ }^{\circ} \mathrm{C}$ for 1 hour in an oven under air stream. The lead precursors used in this work are $\mathrm{PbCl}_{2}, \mathrm{~Pb}(\mathrm{OAc})_{2}, \mathrm{~Pb}\left(\mathrm{NO}_{3}\right)_{2}, \mathrm{~Pb}(\text { acac })_{2}$ and $\mathrm{PbCO}_{3}$.

\section{Hole transport layer (HTM) deposition}

A 300-400 nm-thick HTM was deposited on top of the perovskite substrates by spin coating at 4000 r.p.m for $30 \mathrm{~s}$ under air conditions, using $100 \mu \mathrm{L}$ of spiro-OMeTAD solution. The spiro-OMeTAD solution was prepared by dissolving $72.3 \mathrm{mg}$ of $\left(2,2^{\prime}, 7,7^{\prime}\right.$-tetrakis $\left(N, N^{\prime}\right.$-di- $p$-methoxyphenylamine $)$ - 9,9'-spirobifluorene), $28.8 \mu \mathrm{L}$ of 4 -tert-butylpyridine and $17.5 \mu \mathrm{L}$ of a stock solution of $520 \mathrm{mg} \mathrm{mL}^{-1}$ of lithium bis(trifluoromethylsulfonyl)imide in acetonitrile, in $1 \mathrm{~mL}$ of chlorobenzene.

\section{Gold electrode deposition}

The deposition of $60 \mathrm{~nm}$ of gold was performed by thermal evaporation under ultrahigh vacuum conditions, using a commercial MBraun vacuum chamber. Before beginning the evaporation, the chamber was evacuated until a pressure of $1 \times 10^{-6}$ mbar was reached.

\section{Perovskite film characterization}

The morphology and structural properties of the films were analyzed using a JEOL 7001F scanning electron microscope with a film emission gun (SEMFEG) and a Bruker AXS-D4 Endeaver Advance X-ray diffractometer (XRD) using $\mathrm{Cu} \mathrm{K} \alpha$ radiation. The PL spectra of the films were registered by using a spectrophotometer based on a CCD (Andor i-DUS DV420A-OE) coupled with a spectrograph as a diffraction grating (Newport 77400). A commercial laser diode $\left(532 \mathrm{~nm}, 52 \mathrm{~mW} \mathrm{~cm}^{-2}\right.$ ) was used as an excitation source, whose power intensity was adjusted by means of neutral density filters.

\section{Solar cell characterization}

The Incident Photon to Current Efficiency (IPCE) was determined using a xenon lamp power source coupled with a monochromator controlled by a computer; the photocurrent was measured using an optical power meter 70310 from Oriel Instruments and a $\mathrm{Si}$ photodiode to calibrate the system. Current density-voltage $(J-V)$ curves were obtained under 1 sun illumination (100 $\mathrm{mW} \mathrm{cm}^{-2}$ ) using a xenon arc lamp simulator (Sun 2000, ABET Technologies) with an AM 1.5G spectral filter and a Keithley 2400, previously calibrated with an NREL-calibrated Si solar cell. All the measurements were performed with an opaque mask of $0.08 \mathrm{~cm}^{2}$ and without encapsulation. The electrochemical impedance spectroscopy measurements were carried out by means of a FRA equipped PGSTAT-30 from Autolab under 1 sun illumination conditions at different applied voltages and applying a $30 \mathrm{mV} \mathrm{A} / \mathrm{C}$ voltage perturbation over the constant applied bias with a frequency ranging from $1 \mathrm{MHz}$ to $10 \mathrm{mHz}$.

\section{Results and discussion}

With the aim to evaluate the possibility of using non-halide lead sources for the synthesis of perovskite films, we have chosen different lead non-halide reagents: $\mathrm{Pb}(\mathrm{OAc})_{2}, \mathrm{~Pb}\left(\mathrm{NO}_{3}\right)_{2}$, $\mathrm{Pb}(\text { acac })_{2}$ and $\mathrm{PbCO}_{3}$. For comparison purposes, we decided to contrast the results obtained with these lead precursors with those achieved in our laboratory with the $\mathrm{PbCl}_{2}$ precursor as a reference. Perovskite films were synthesized as explained in the experimental section. These thin films, obtained using the different lead precursors, were analyzed by X-Ray Diffraction (XRD). For this purpose, all the perovskite films were prepared onto a mesoporous $\mathrm{TiO}_{2}$ scaffold, by spin-coating of a DMF 
solution of the corresponding lead precursor and $\mathrm{CH}_{3} \mathrm{NH}_{3} \mathrm{I}$ in a $1: 3$ ratio due to stoichiometric reasons. After the deposition, films were annealed at $100{ }^{\circ} \mathrm{C}$ (exact details in the Experimental section). The fastest formation of perovskite was observed when using $\mathrm{Pb}(\mathrm{OAc})_{2}$, probably due to the lower melting point of the excess methylammonium acetate, which is formed as a result of the excess of $\mathrm{CH}_{3} \mathrm{NH}_{3} \mathrm{I}$ employed, see Scheme 1. The reaction between the lead source and $\mathrm{CH}_{3} \mathrm{NH}_{3} \mathrm{I}$ in a $1: 3$ ratio led to the formation of perovskite $\mathrm{CH}_{3} \mathrm{NH}_{3} \mathrm{PbI}_{3}$ and excess of the corresponding methylammonium salt, which was eliminated during the annealing procedure, in agreement with the observations realized by other authors. ${ }^{27,28}$

XRD measurements of the different perovskite films allowed us to confirm that precursors $\mathrm{Pb}(\mathrm{OAc})_{2}, \mathrm{~Pb}\left(\mathrm{NO}_{3}\right)_{2}$ and $\mathrm{Pb}(\mathrm{acac})_{2}$ are suitable candidates for the preparation of $\mathrm{CH}_{3} \mathrm{NH}_{3} \mathrm{PbI}_{3}$ (see Fig. 1). The failure of $\mathrm{PbCO}_{3}$ in the formation of perovskite was attributed to its low solubility in DMF, even at $80{ }^{\circ} \mathrm{C}$ (not shown in Fig. 1). In all the cases analyzed in Fig. 1, diffraction peaks of $\mathrm{CH}_{3} \mathrm{NH}_{3} \mathrm{PbI}_{3}$ are clearly recognized indicating the formation of this perovskite when using the four different lead precursors. $\mathrm{PbCl}_{2}, \mathrm{~Pb}(\mathrm{OAc})_{2}$ and $\mathrm{Pb}\left(\mathrm{NO}_{3}\right)_{2}$ produce $\mathrm{CH}_{3} \mathrm{NH}_{3} \mathrm{PbI}_{3}$ films with preferential (110) orientation, especially the former two, as can be deduced from the relative intensities between diffraction peaks in comparison with powder samples. As previously observed, the presence of a minor peak at $2 \theta \sim 12.75{ }^{\circ} \mathrm{C}$ indicates that traces of $\mathrm{PbI}_{2}$ remain in the film. ${ }^{17}$ This peak is sensibly reduced when $\mathrm{Pb}\left(\mathrm{NO}_{3}\right)_{2}$ is used as a lead precursor. The presence of the $\mathrm{PbI}_{2}$ phase does not imply necessarily a deleterious effect for device performance, as it has been reported a passivation effect of $\mathrm{CH}_{3} \mathrm{NH}_{3} \mathrm{PbI}_{3}$ by $\mathrm{PbI}_{2} \cdot{ }^{29}$ The intensity of this peak increases for $\mathrm{Pb}(\text { acac })_{2}$, suggesting that in this case the reaction is not complete. Note that different precursors are compared using the same experimental procedures, probably a film and subsequent photovoltaic device will require a different optimized preparation procedure for each precursor for an optimum behavior. Moreover, the presence of additional peaks in the XRD spectrum of the perovskite film, corresponding to the substrate (FTO and $\mathrm{TiO}_{2}$ ), for $\mathrm{Pb}(\mathrm{acac})_{2}$ and to a lesser extent in $\mathrm{Pb}\left(\mathrm{NO}_{3}\right)_{2}$ precursor, suggests that further optimization of the reaction process is needed.

Absorbance data also proved that perovskite $\mathrm{CH}_{3} \mathrm{NH}_{3} \mathrm{PbI}_{3}$ can be synthesized from the non-halide lead reagents $\mathrm{Pb}(\mathrm{OAc})_{2}$, $\mathrm{Pb}\left(\mathrm{NO}_{3}\right)_{2}$ and $\mathrm{Pb}(\mathrm{acac})_{2}$, by comparison with the spectra obtained when using $\mathrm{PbCl}_{2}$. As can be seen in Fig. 2a (normalized absorption spectra), all non-halide precursors and reference formed perovskite films that present similar absorption spectra features. However, the absorption signal for $\mathrm{Pb}\left(\mathrm{NO}_{3}\right)_{2}$ is deformed in comparison with the reference sample. This effect

$$
\begin{array}{ll}
\mathrm{PbX}_{2}+3 \mathrm{CH}_{3} \mathrm{NH}_{3} \mathrm{I} \frac{\mathrm{DMF}}{100^{\circ} \mathrm{C}}-\mathrm{CH}_{3} \mathrm{NH}_{3} \mathrm{Pbl}+2 \mathrm{CH}_{3} \mathrm{NH}_{3} \mathrm{X} \\
\mathrm{X}=\mathrm{Cl}^{-}, \mathrm{OAc}^{-}, \mathrm{NO}_{3}^{-}, \mathrm{acac}^{-} & 2 \mathrm{CH}_{3} \mathrm{NH}_{2}+2 \mathrm{HX}
\end{array}
$$

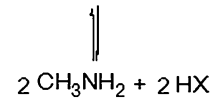

Scheme 1 General reactions proposed for the synthesis of $\mathrm{CH}_{3} \mathrm{NH}_{3}-$ $\mathrm{Pbl}_{3}$ perovskite from different lead precursors.

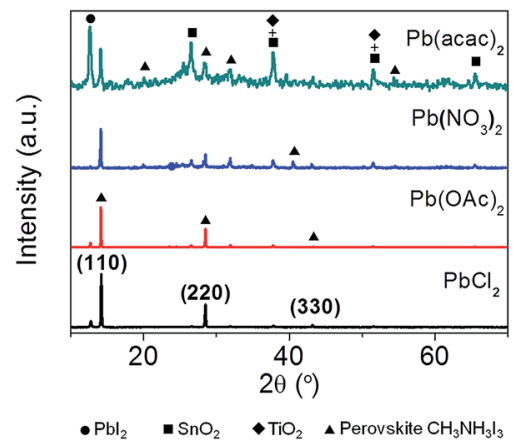

Fig. 1 XRD of the films prepared with different lead precursors, with the exception of $\mathrm{PbCO}_{3}$ that does not produce $\mathrm{CH}_{3} \mathrm{NH}_{3} \mathrm{Pbl}_{3}$ using the common synthesis procedure employed.

arises from the light scattering of the sample mainly due to the non-homogeneous film deposition when using this lead source. Besides, the intensity of the absorption spectrum is significantly lower (Fig. S1, ESI $\dagger$ ), thus suggesting that although perovskite $\mathrm{CH}_{3} \mathrm{NH}_{3} \mathrm{PbI}_{3}$ is formed, further improvement is needed in order to obtain an optimal amount and quality of the perovskite deposited. Additionally, photoluminescence data (Fig. 2b) confirmed that all the samples showed the same emission pattern regardless of the lead precursor employed for the perovskite preparation. Curiously, a small shift in the maximum for each emission is observed depending on the lead source, which could be attributed to the different morphology of the perovskite crystal of each film sample. In fact, previous
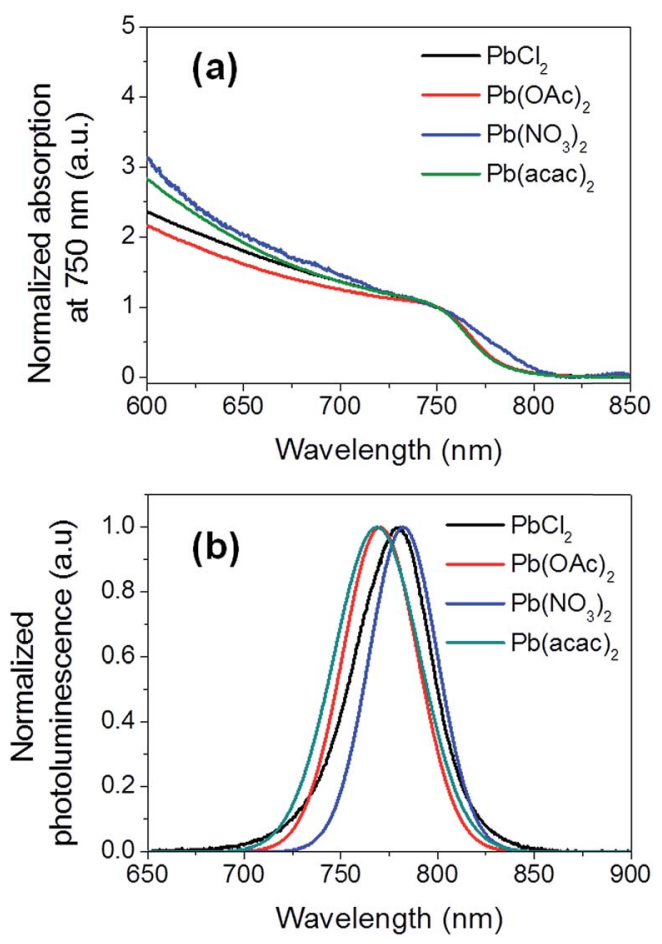

Fig. 2 (a) Light absorption spectra normalized at $750 \mathrm{~nm}$ and (b) normalized photoluminescence of the films prepared with different lead precursors. 
studies revealed a direct influence of the crystal size on the optical properties of the perovskite films. ${ }^{\mathbf{3 0 , 3 1}}$ Particularly, a slight blue-shift of the absorption and photoluminescence signals is observed for small crystallites. In any case, further studies are required for elucidating the fundamentals of this phenomenon; nevertheless these issues are out of the scope of this work.

The morphology of the perovskite films, using $\mathrm{Pb}(\mathrm{OAc})_{2}$ and $\mathrm{PbCl}_{2}$ precursors, was analyzed by using a scanning electron microscope. Fig. 3 shows the SEM images taken from samples with and without $\mathrm{TiO}_{2}$ mesoporous scaffold configuration. Samples prepared with a $\mathrm{TiO}_{2}$ mesoporous scaffold present an overlayer of perovskite that does not cover completely the mesoporous layer, see Fig. 3c and d. Interestingly, smaller crystal sizes of perovskite were obtained for the case of $\mathrm{Pb}(\mathrm{OAc})_{2}$ (in both configurations flat and with mesoporous scaffold), probably due to the fast crystallization, in comparison with the $\mathrm{PbCl}_{2}$ precursor, detected when using this reagent. These results reflect how the type of lead precursor utilized for the growth of $\mathrm{CH}_{3} \mathrm{NH}_{3} \mathrm{PbI}_{3}$ affects dramatically the morphological properties of perovskite layers.

$\mathrm{XRD}$ analysis clearly establishes the preparation of perovskite $\mathrm{CH}_{3} \mathrm{NH}_{3} \mathrm{PbI}_{3}$ films from non-halide lead precursors, but different morphological properties have been revealed by SEM micrograph analysis. In order to study the influence on the final photovoltaic performance, PSCs have been prepared using the different lead precursors under study. All devices were prepared using the same experimental procedure (details in the Experimental section). Fig. 4 and Table 1 present the performance of the best PSCs obtained from each lead precursor. As can be seen, only PSCs prepared from $\mathrm{Pb}(\mathrm{OAc})_{2}$ gave satisfactory results in terms of efficiency, comparable to those obtained with the reference $\mathrm{PbCl}_{2}$ precursor (entries 2 and 1, respectively). On the other hand, $\mathrm{Pb}\left(\mathrm{NO}_{3}\right)_{2}$ and $\mathrm{Pb}(\text { acac })_{2}$ gave PSCs with low efficiencies (entries 3 and 4, respectively). These results
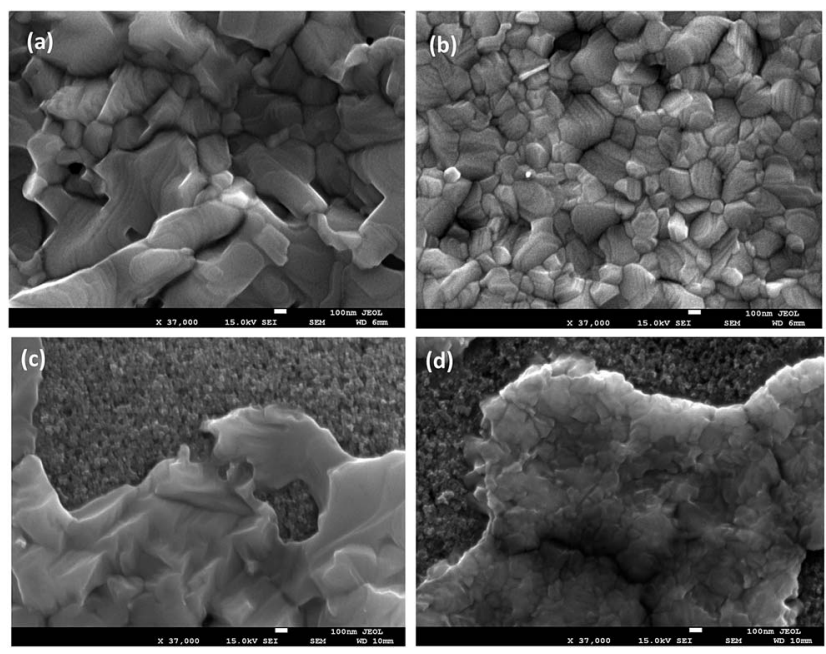

Fig. 3 SEM picture of $\mathrm{CH}_{3} \mathrm{NH}_{3} \mathrm{Pbl}_{3}$ perovskite layer growth on a flat substrate with (a) $\mathrm{PbCl}_{2}$ and (b) $\mathrm{Pb}(\mathrm{OAc})_{2}$ lead precursors, and on a substrate with a mesoporous $\mathrm{TiO}_{2}$ scaffold with (c) $\mathrm{PbCl}_{2}$ and (d) $\mathrm{Pb}(\mathrm{OAc})_{2}$ lead precursors. Scale bar represents $100 \mathrm{~nm}$.

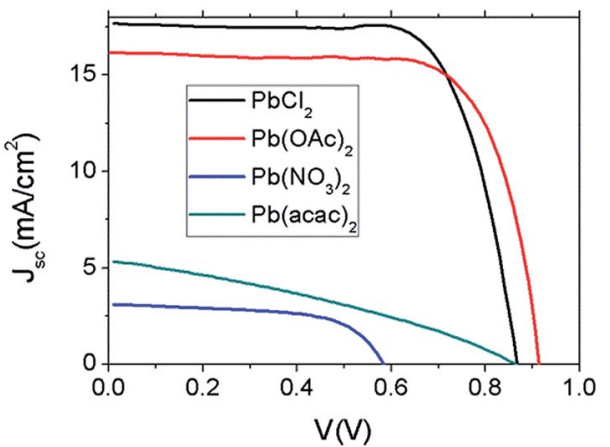

Fig. $4 \mathrm{~J}-V$ curve for PSCs prepared with different lead precursors using a $200 \mathrm{~nm} \mathrm{TiO}_{2}$ mesoporous scaffold layer. Champion cells obtained for each lead precursor are represented. J-V curves were scanned from positive voltage to zero, at a scan rate of $50 \mathrm{mV} \mathrm{s}^{-1}$.

demonstrate that perovskites for solar cell devices can be prepared from lead sources different to the conventional halide precursors $\mathrm{PbCl}_{2}$ or $\mathrm{PbI}_{2}$. In addition, the PSC performance depends dramatically on the lead precursor employed, and optimum performance should require a different optimization of growth conditions and preparation. An important correlation between solar cell efficiency and lead precursor was previously reported for quantum dot sensitized solar cells using $\mathrm{PbS}$ as a light absorbing material. ${ }^{32}$ In that case, a clear influence of the lead precursor on the trap states was established.

Cells using the two precursors presenting the highest efficiencies, $\mathrm{PbCl}_{2}$ and $\mathrm{Pb}(\mathrm{OAc})_{2}$, have been prepared with different configurations, i.e. $\mathrm{TiO}_{2}$ or $\mathrm{Al}_{2} \mathrm{O}_{3}$ scaffolds or without any scaffold (details in the Experimental section). From the data shown in Table 2, it can be concluded that the best results in terms of efficiency were obtained when using a configuration with a mesoporous $\mathrm{TiO}_{2}$ layer of $200 \mathrm{~nm}$. In all the configurations studied, $\mathrm{Pb}(\mathrm{OAc})_{2}$ provided lower efficiency than samples prepared with $\mathrm{PbCl}_{2}$, however it is important to note that the deposition technique employed for both precursors was the same, these procedures being only optimized for $\mathrm{PbCl}_{2}$. All these results are promising regarding the preparation of high efficiency PSCs from non-halide lead precursors, though additional research is needed to find the optimum deposition conditions, presumably different to the ones employed for

Table 1 Solar cell parameters under 1 sun illumination: short circuit current, $J_{\mathrm{sc}}$, open circuit potential, $V_{\mathrm{oc}}$, fill factor, $\mathrm{FF}$, and photoconversion efficiency, $\eta$, as obtained from best PSC performances by using $\mathrm{PbCl}_{2}, \mathrm{~Pb}(\mathrm{OAc})_{2}, \mathrm{~Pb}\left(\mathrm{NO}_{3}\right)_{2}$ and $\mathrm{Pb}(\mathrm{acac})_{2}$ as lead sources for the synthesis of the perovskite. Cells were prepared using a $200 \mathrm{~nm} \mathrm{TiO} 2$ mesoporous scaffold

\begin{tabular}{llllll}
\hline Entry & Precursor & $J_{\text {sc }}\left(\mathrm{mA} \mathrm{cm}^{-2}\right)$ & $V_{\text {oc }}(\mathrm{V})$ & FF $(\%)$ & Efficiency (\%) \\
\hline 1 & $\mathrm{PbCl}_{2}$ & 17.67 & 0.867 & 72.6 & 11.1 \\
2 & $\mathrm{~Pb}(\mathrm{OAc})_{2}$ & 16.2 & 0.915 & 72.8 & 10.8 \\
3 & $\mathrm{~Pb}\left(\mathrm{NO}_{3}\right)_{2}$ & 3.12 & 0.584 & 60.3 & 1.1 \\
4 & $\mathrm{~Pb}(\mathrm{acac})_{2}$ & 5.39 & 0.860 & 33.3 & 1.5
\end{tabular}


Table 2 Different configurations for the PSCs using $\mathrm{Pb}(\mathrm{OAc})_{2}$ and $\mathrm{PbCl}_{2}$ as lead sources. IPCE of each cell was measured and integrated, achieving good agreement with the measured photocurrent obtained in most of the cases

\begin{tabular}{|c|c|c|c|c|c|c|}
\hline Entry & Device & $J_{\mathrm{sc}}\left(\mathrm{mA} \mathrm{cm}{ }^{-2}\right)$ & $J$ from IPCE & $V_{\mathrm{oc}}(\mathrm{V})$ & $\mathrm{FF}(\%)$ & Efficiency (\%) \\
\hline 1 & Flat_PbCl 2 & 13.57 & 13.81 & 1.023 & 59.1 & 8.2 \\
\hline 2 & Flat_Pb(OAc $)_{2}$ & 15.11 & 12.46 & 0.992 & 33.5 & 5.0 \\
\hline 4 & $\mathrm{Al}_{2} \mathrm{O}_{3} \_\mathrm{Pb}(\mathrm{OAc})_{2}$ & 4.15 & 2.90 & 0.940 & 61.3 & 2.4 \\
\hline 5 & $\mathrm{TiO}_{2} \_\mathrm{PbCl}_{2}$ & 17.67 & 15.36 & 0.867 & 72.6 & 11.1 \\
\hline 6 & $\mathrm{TiO}_{2} \mathrm{~Pb}(\mathrm{OAc})_{2}$ & 13.48 & 13.47 & 0.834 & 65.5 & 7.4 \\
\hline
\end{tabular}

$\mathrm{PbCl}_{2}$. It is noteworthy that the use of $\mathrm{Pb}(\mathrm{OAc})_{2}$ allowed the preparation of flat perovskite solar cells (without scaffold), whereas this configuration is not straightforward when using $\mathrm{PbI}_{2}$ instead of $\mathrm{PbCl}_{2} \cdot{ }^{33}$ This fact adds an additional degree of versatility in the use of $\mathrm{Pb}(\mathrm{OAc})_{2}$ as a lead source.

Moreover, it is also interesting to highlight that an important cell parameter, open circuit potential, $V_{\text {oc }}$, depends more strongly on PSC configuration than on the lead precursor employed. A lower $V_{\text {oc }}$ is observed when the $\mathrm{TiO}_{2}$ scaffold is used in comparison with samples prepared using the $\mathrm{Al}_{2} \mathrm{O}_{3}$ scaffold or no-scaffold, see Table 2. From impedance spectroscopy characterization, see Fig. 5, it can be clearly observed that at high applied bias, samples with the $\mathrm{TiO}_{2}$ scaffold present a lower recombination resistance, $R_{\text {rec }}$, than flat samples, indicating a lower recombination rate for planar cells. Nevertheless, few differences are detected regarding the lead precursors when samples using the same configuration are compared. $R_{\text {rec }}$ has been obtained by fitting the impedance spectra with the equivalent circuits previously described..$^{\mathbf{1 0}, 34}$ These results are in good agreement with the lower recombination rate, and consequently higher $V_{\text {oc }}$, observed for $\mathrm{CH}_{3} \mathrm{NH}_{3} \mathrm{PbI}_{3}$ perovskite in a flat device ${ }^{35}$ and in samples with the $\mathrm{Al}_{2} \mathrm{O}_{3}$ scaffold, ${ }^{10}$ in comparison with samples using the $\mathrm{TiO}_{2}$ scaffold, where just halide lead precursors were used for perovskite formation.

The use of different lead precursors leads to the preparation of perovskite layers with different morphological properties, producing photovoltaic devices with different performances. In

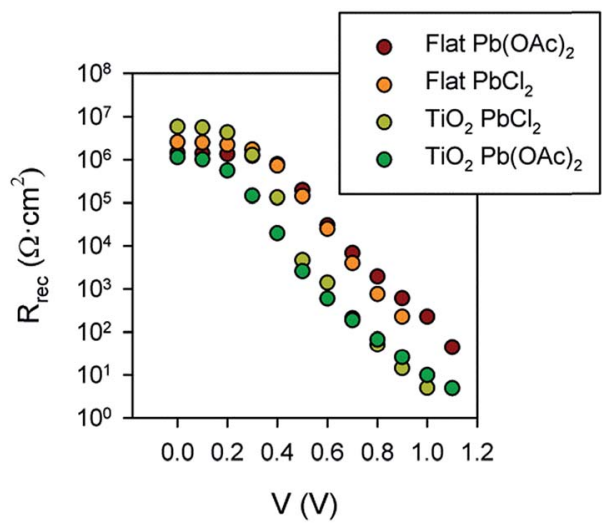

Fig. 5 Recombination resistance, $R_{\mathrm{rec}}$ PSCs prepared with $\mathrm{Pb}(\mathrm{OAc})_{2}$ and $\mathrm{PbCl}_{2}$ as lead precursors, for flat and $\mathrm{TiO}_{2}$ scaffold configurations. order to unveil further influence of lead precursors on another important cell issue, i.e., stability, we have carried out preliminary stability studies of perovskite films and devices under three different conditions of atmosphere and illumination: (i) air with light (A), (ii) air without light (B) and (iii) $\mathrm{N}_{2}$ atmosphere without light (C). Samples tested under A conditions were left under lab ambient illumination. These studies were performed for perovskites obtained from $\mathrm{PbCl}_{2}$ and $\mathrm{Pb}(\mathrm{OAc})_{2}$ precursors. Fig. 6 shows the cell parameters of the devices prepared and stored under conditions A and B for several days. It can be clearly observed that independent of the precursor, cells stored under ambient lab illumination (conditions A) present a continuous decrease of their efficiency, showing an efficiency just $\sim 20 \%$ of the initial one after 15 days of exposure to conditions A. This efficiency decrease can be attributed mainly to a decrease of photocurrent, and additionally to a reduction of the FF. Noteworthily, the decrease in cell performance is slightly higher in the case of devices prepared from $\mathrm{Pb}(\mathrm{OAc})_{2}$ than for the analogues from $\mathrm{PbCl}_{2}$. Moreover, under dark storage

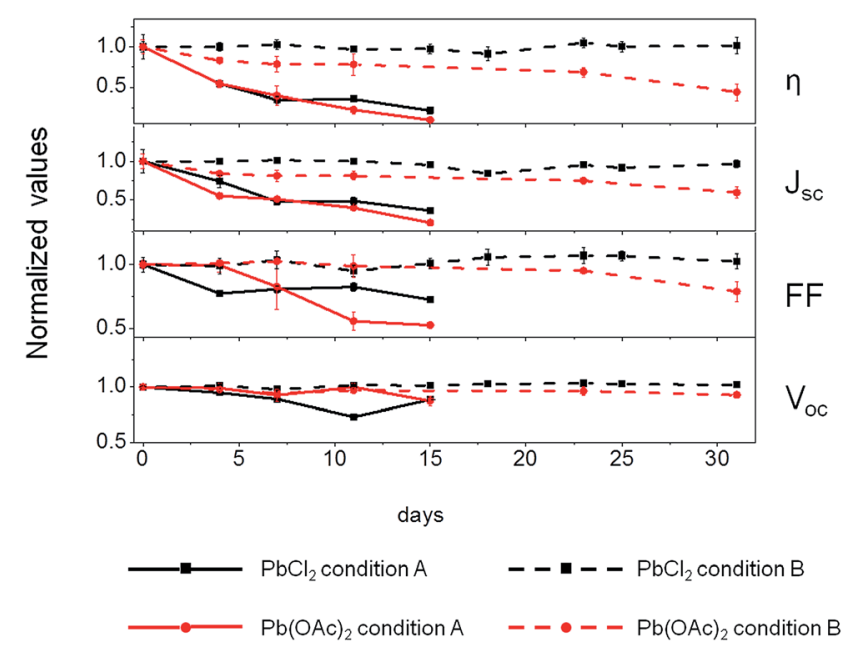

Fig. 6 Normalized cell parameters short circuit current, $J_{s c}$ open circuit potential, $V_{\text {oc }}$, fill factor, FF, and photoconversion efficiency, $\eta$, to the values obtained after device preparation (day 0). Parameters measured under 1 sun illumination at different times after preparation. Values represented are average values of 10 samples and error bars indicate the standard deviation. Samples were stored under conditions A (air with light) and condition B (air without light). The parameter values were obtained from the $J-V$ curves scanned from positive voltage to zero, at a scan rate of $50 \mathrm{mV} \mathrm{s}^{-1}$. 
conditions instead of lab illumination (conditions $\mathrm{B}$ ), the performance of reference cells, using the $\mathrm{PbCl}_{2}$ precursor, presents a good stability after 32 days. However, during this period the efficiency of cells prepared from $\mathrm{Pb}(\mathrm{OAc})_{2}$ was reduced to $\sim 40 \%$ of the initial value. Under conditions $\mathrm{C}$, the stability increases even further and efficiencies around $97 \%$ and $84 \%$ of the initial values are preserved after two months for samples prepared with $\mathrm{PbCl}_{2}$ and $\mathrm{Pb}(\mathrm{OAc})_{2}$, respectively (see ESI, Table S1 and Fig. S4 $\dagger$ ). This study reflects that lead precursors not only affect the film morphology or cell performance, but also the device stability. These aspects have to be considered for further optimization of the cell performance and stability using non-conventional precursors.

Finally, the stability of the perovskite films, without HTM, was studied by recording the absorption spectra of the perovskite films for 40 days (Fig. $55 \dagger$ ) and taking pictures of them to observe their degradation (Fig. S6 $\dagger$ ). An analogous trend to that observed for complete devices has been obtained for perovskite films. These results indicate that the main cause of the loss of efficiency in PSC using spiro-OMeTAD as a HTM is the degradation of the perovskite layer. The use of CuSCN as an alternative HTL can reduce perovskite degradation. ${ }^{36}$ It is also important to remark the important effect of photodegradation, in good agreement with previous reports. ${ }^{36}$ Future development of this technology will require the consideration of these stability issues, where employed precursors play an important role, in addition to the high efficiency.

The literature on the preparation of $\mathrm{CH}_{3} \mathrm{NH}_{3} \mathrm{PbI}_{3}$ PSCs reflects the high versatility of this material, which can be produced from a large variety of preparation methods, the most relevant being the single step solution process, ${ }^{7}$ sequential deposition, ${ }^{21}$ vapor deposition ${ }^{23}$ and use of solvent engineering, ${ }^{1}$ among others. This versatility has had important consequences as the fast enhancement of the efficiencies reported for PSCs has been obtained by an empirical optimization of the perovskite deposition method. In addition to this, in this article we show the existence of another important factor that can affect the perovskite growth process, the precursor employed in the synthesis. In the case of non-halide lead precursors, their corresponding anions are not incorporated into the perovskite structure. However, it does not mean that these anions are mere spectators of the perovskite synthesis, as they affect the final characteristics, from the morphological, optical, electrical and stability points of view.

Another interesting feature affected by the results presented here is related to one of the first discussions that arose in this field, i.e. the role of $\mathrm{Cl}$ in the performance of PSCs. Since the seminal publication of Snaith and Miyasaka ${ }^{6}$ employing $\mathrm{PbCl}_{2}$ for the preparation of perovskites, there has been an interesting debate about the role of $\mathrm{Cl}$. While some authors have pointed out that $\mathrm{Cl}$ is incorporated into the perovskite crystalline structure, which produces $\mathrm{CH}_{3} \mathrm{NH}_{3} \mathrm{PbI}_{3-x} \mathrm{Cl}_{x}$ perovskite instead of the pure iodine $\mathrm{CH}_{3} \mathrm{NH}_{3} \mathrm{PbI}_{3}$, thus slowing down the nucleation dynamics, ${ }^{37,38}$ others have recently claimed that perovskite prepared from the chloride precursor yields a perovskite film consisting of a combination of $\mathrm{CH}_{3} \mathrm{NH}_{3} \mathrm{PbI}_{3}$ and $\mathrm{CH}_{3} \mathrm{NH}_{3} \mathrm{PbCl}_{3}{ }^{39}$ However, most of the studies focusing on the physical properties of these materials have established that the use of $\mathrm{PbCl}_{2}$ affects dramatically the properties of the perovskite film, such as a significant increase of the diffusion length of free carriers (exceeding $1 \mu \mathrm{m}$ ) and photoluminescence lifetime, ${ }^{\mathbf{4 0 , 4 1}}$ properties that are crucial for the development of highly efficient devices. Nevertheless, the exact amount of $\mathrm{Cl}$ incorporated into the crystalline structure was very small (below $3-4 \%$ ) ${ }^{42}$ or even below the detection limit of the techniques employed in the compositional analysis. ${ }^{\mathbf{4 3}}$ Therefore, the combination of iodide and chloride lead precursors reflects a strong influence of morphology, thus affecting the final cell performance. ${ }^{43,44}$ The results in this work point in the same direction, extending the influence of the lead precursor on perovskite properties to non-halide precursors.

\section{Conclusions}

We have prepared $\mathrm{CH}_{3} \mathrm{NH}_{3} \mathrm{PbI}_{3}$ perovskite films and PSCs using different lead precursors. We have obtained devices with significant efficiency with the non-halide sources $\mathrm{Pb}\left(\mathrm{NO}_{3}\right)_{2}$, $\mathrm{Pb}(\mathrm{acac})_{2}$ and $\mathrm{Pb}(\mathrm{OAc})_{2}$, reaching efficiencies close to the reference cells prepared with $\mathrm{PbCl}_{2}$ for the case of precursor $\mathrm{Pb}(\mathrm{OAc})_{2}$. We propose a similar reaction process when a lead precursor different to $\mathrm{PbI}_{2}$ is used. In that case, a $3: 1$ molar ratio between $\mathrm{CH}_{3} \mathrm{NH}_{3} \mathrm{I}$ and $\mathrm{PbX}_{2}$ is needed to ensure the final stoichiometry of perovskite $\mathrm{CH}_{3} \mathrm{NH}_{3} \mathrm{PbI}_{3}$. By using these experimental conditions, an excess of methylammonium salt remains unreacted, in contrast when using $\mathrm{PbI}_{2}$ and $\mathrm{CH}_{3} \mathrm{NH}_{3} \mathrm{I}$ in a 1:1 molar ratio. However, the use of non-iodine lead precursors influences the final properties of the $\mathrm{CH}_{3} \mathrm{NH}_{3} \mathrm{PbI}_{3}$ perovskite films, provoking important implications in the final solar cell performance. We have observed that the morphology of perovskite films, the photoconversion efficiencies and the stability of the devices are strongly influenced by the lead precursor used. The use of the $\mathrm{Pb}(\mathrm{OAc})_{2}$ precursor has produced cells with efficiencies very close to the reference samples prepared with $\mathrm{PbCl}_{2}$, being a promising precursor for further improvement of PSC performance, but presenting lower long term stability than reference. The preparation of PSCs from non-halide lead precursors, different to the normally used $\mathrm{PbI}_{2}$ and $\mathrm{PbCl}_{2}$, clarifies some former questions on perovskite synthesis and properties. The use of non-halide sources opens a new research line in concordance with the use of non-passive reactants for the optimization of this kind of solar cell. These non-passive reactants might affect the final film properties, not only in terms of efficiency but also in stability.

\section{Acknowledgements}

This work was supported by MINECO of Spain under project MAT2013-47192-C3-1-R, Universitat Jaume I project 12I361.01/ 1, E.M.-M thanks the Ramón y Cajal program, and R.S.S. thanks the FP7 European project ALLOXIDE (309018).

\section{References}

1 N. J. Jeon, J. H. Noh, Y. C. Kim, W. S. Yang, S. Ryu and S. I. Seok, Nat. Mater., 2014, 13, 897-903. 
2 N.-G. Park, J. Phys. Chem. Lett., 2013, 4, 2423-2429.

3 H. J. Snaith, J. Phys. Chem. Lett., 2013, 4, 3623-3630.

4 A. Kojima, K. Teshima, Y. Shirai and T. Miyasaka, J. Am. Chem. Soc., 2009, 131, 6050-6051.

5 http://www.nrel.gov/ncpv/images/efficiency_chart.jpg.

6 M. M. Lee, J. Teuscher, T. Miyasaka, T. N. Murakami and H. J. Snaith, Science, 2012, 338, 643-647.

7 H.-S. Kim, C.-R. Lee, J.-H. Im, K.-B. Lee, T. Moehl, A. Marchioro, S.-J. Moon, R. Humphry-Baker, J.-H. Yum, J. E. Moser, M. Gratzel and N.-G. Park, Sci. Rep., 2012, 2, 591.

8 E. Edri, S. Kirmayer, D. Cahen and G. Hodes, J. Phys. Chem. Lett., 2013, 4, 897-902.

9 J. H. Noh, S. H. Im, J. H. Heo, T. N. Mandal and S. I. Seok, Nano Lett., 2013, 13, 1764-1769.

10 B. Suarez, V. Gonzalez-Pedro, T. S. Ripolles, R. S. Sanchez, L. Otero and I. Mora-Sero, J. Phys. Chem. Lett., 2014, 5, 1628-1635.

11 G. E. Eperon, S. D. Stranks, C. Menelaou, M. B. Johnston, L. M. Herz and H. J. Snaith, Energy Environ. Sci., 2014, 7, 982-988.

12 F. C. Hanusch, E. Wiesenmayer, E. Mankel, A. Binek, P. Angloher, C. Fraunhofer, N. Giesbrecht, J. M. Feckl, W. Jaegermann, D. Johrendt, T. Bein and P. Docampo, J. Phys. Chem. Lett., 2014, 5, 2791-2795.

13 T. M. Koh, K. Fu, Y. Fang, S. Chen, T. C. Sum, N. Mathews, S. G. Mhaisalkar, P. P. Boix and T. Baikie, J. Phys. Chem. C, 2013, 118, 16458-16462.

14 N. Pellet, P. Gao, G. Gregori, T.-Y. Yang, M. K. Nazeeruddin, J. Maier and M. Grätzel, Angew. Chem., Int. Ed., 2014, 53, 3151-3157.

15 L. Badia, E. Mas-Marzá, R. S. Sánchez, E. M. Barea, J. Bisquert and I. Mora-Seró, APL Mater., 2014, 2, 081507.

16 J. H. Noh, N. J. Jeon, Y. C. Choi, M. K. Nazeeruddin, M. Gratzel and S. I. Seok, J. Mater. Chem. A, 2013, 1, 11842-11847.

17 S. Chavhan, O. Miguel, H.-J. Grande, V. Gonzalez-Pedro, R. S. Sanchez, E. M. Barea, I. Mora-Sero and R. Tena-Zaera, J. Mater. Chem. A, 2014, 2, 12754-12760.

18 J. A. Christians, R. C. M. Fung and P. V. Kamat, J. Am. Chem. Soc., 2013, 136, 758-764.

19 P. Qin, S. Tanaka, S. Ito, N. Tetreault, K. Manabe, H. Nishino, M. K. Nazeeruddin and M. Grätzel, Nat. Commun., 2014, 5, 3834.

20 H. Zhou, Q. Chen, G. Li, S. Luo, T.-b. Song, H.-S. Duan, Z. Hong, J. You, Y. Liu and Y. Yang, Science, 2014, 345, 542-546.

21 J. Burschka, N. Pellet, S.-J. Moon, R. Humphry-Baker, P. Gao, M. K. Nazeeruddin and M. Graetzel, Nature, 2013, 499, 316319.

22 J.-H. Im, I.-H. Jang, N. Pellet, M. Grätzel and N.-G. Park, Nat. Nanotechnol., 2014, 9, 927-932.

23 M. Liu, M. B. Johnston and H. J. Snaith, Nature, 2013, 501, 395-398.
24 A. Buin, P. Pietsch, J. Xu, O. Voznyy, A. H. Ip, R. Comin and E. H. Sargent, Nano Lett., 2014.

25 D. T. Moore, H. Sai, K. Wee Tan, L. A. Estroff and U. Wiesner, APL Mater., 2014, 2, 081802.

26 A. Poglitsch and D. Weber, J. Chem. Phys., 1987, 87, 63736378.

27 A. Dualeh, P. Gao, S. I. Seok, M. K. Nazeeruddin and M. Grätzel, Chem. Mater., 2014, 26, 6160-6164.

28 Y. Zhao and K. Zhu, J. Am. Chem. Soc., 2014, 136, 1224112244.

29 Q. Chen, H. Zhou, T.-B. Song, S. Luo, Z. Hong, H.-S. Duan, L. Dou, Y. Liu and Y. Yang, Nano Lett., 2014, 14, 4158-4163.

30 V. DInnocenzo, G. Grancini, M. J. P. Alcocer, A. R. S. Kandada, S. D. Stranks, M. M. Lee, G. Lanzani, H. J. Snaith and A. Petrozza, Nat. Commun., 2014, 5, 3586.

31 M. De Bastiani, V. D'Innocenzo, S. D. Stranks, H. J. Snaith and A. Petrozza, APL Mater., 2014, 2, 081509.

32 V. Gonzalez-Pedro, C. Sima, G. Marzari, P. P. Boix, S. Gimenez, Q. Shen, T. Dittrich and I. Mora-Sero, Phys. Chem. Chem. Phys., 2013, 15, 13835-13843.

33 H.-S. Kim, I. Mora-Sero, V. Gonzalez-Pedro, F. FabregatSantiago, E. J. Juarez-Perez, N.-G. Park and J. Bisquert, Nat. Commun., 2013, 4, 2242.

34 E. J. Juarez-Perez, R. S. Sanchez, L. Badia, G. GarciaBelmonte, Y. S. Kang, I. Mora-Sero and J. Bisquert, J. Phys. Chem. Lett., 2014, 5, 2390-2394.

35 V. Gonzalez-Pedro, E. J. Juarez-Perez, W.-S. Arsyad, E. M. Barea, F. Fabregat-Santiago, I. Mora-Sero and J. Bisquert, Nano Lett., 2014, 14, 888-893.

36 S. Ito, S. Tanaka, H. Vahlman, H. Nishino, K. Manabe and P. Lund, ChemPhysChem, 2014, 15, 1194-1200.

37 H. Yu, F. Wang, F. Xie, W. Li, J. Chen and N. Zhao, Adv. Funct. Mater., 2014, 24, 7102-7108.

38 S. T. Williams, F. Zuo, C.-C. Chueh, C.-Y. Liao, P.-W. Liang and A. K. Y. Jen, ACS Nano, 2014, 8, 10640-10654.

39 B.-w. Park, B. Philippe, T. Gustafsson, K. Sveinbjörnsson, A. Hagfeldt, E. M. J. Johansson and G. Boschloo, Chem. Mater., 2014, 26, 4466-4471.

40 S. D. Stranks, G. E. Eperon, G. Grancini, C. Menelaou, M. J. P. Alcocer, T. Leijtens, L. M. Herz, A. Petrozza and H. J. Snaith, Science, 2013, 342, 341-344.

41 E. Edri, S. Kirmayer, A. Henning, S. Mukhopadhyay, K. Gartsman, Y. Rosenwaks, G. Hodes and D. Cahen, Nano Lett., 2014, 14, 1000-1004.

42 S. Colella, E. Mosconi, P. Fedeli, A. Listorti, F. Gazza, F. Orlandi, P. Ferro, T. Besagni, A. Rizzo, G. Calestani, G. Gigli, F. De Angelis and R. Mosca, Chem. Mater., 2013, 25, 4613-4618.

43 S. Dharani, H. A. Dewi, R. R. Prabhakar, T. Baikie, C. Shi, D. Yonghua, N. Mathews, P. P. Boix and S. G. Mhaisalkar, Nanoscale, 2014, 6, 13854-13860.

44 Y. Zhao and K. Zhu, J. Phys. Chem. C, 2014, 118, 9412-9418. 